\title{
Investigation of electrophoretic deposition as a method for coating complex shaped steel parts in solid oxide cell stacks
}

Talic, B.; Wulff, A. C.; Molin, S.; Andersen, K. B.; Zielke, P.; Frandsen, H. L.

Published in:

Surface and Coatings Technology

Link to article, DOI:

10.1016/j.surfcoat.2019.125093

Publication date:

2019

Document Version

Peer reviewed version

Link back to DTU Orbit

Citation (APA):

Talic, B., Wulff, A. C., Molin, S., Andersen, K. B., Zielke, P., \& Frandsen, H. L. (2019). Investigation of electrophoretic deposition as a method for coating complex shaped steel parts in solid oxide cell stacks. Surface and Coatings Technology, 380, [125093]. https://doi.org/10.1016/j.surfcoat.2019.125093

\section{General rights}

Copyright and moral rights for the publications made accessible in the public portal are retained by the authors and/or other copyright owners and it is a condition of accessing publications that users recognise and abide by the legal requirements associated with these rights.

- Users may download and print one copy of any publication from the public portal for the purpose of private study or research.

- You may not further distribute the material or use it for any profit-making activity or commercial gain

- You may freely distribute the URL identifying the publication in the public portal 


\title{
Investigation of electrophoretic deposition as a method for coating complex shaped steel parts in solid oxide cell stacks
}

\author{
B. Talic*, A.C. Wulff, S. Molin, K. B. Andersen, P. Zielke and H. L. Frandsen \\ Department of Energy Conversion and Storage, Technical University of Denmark, \\ Frederiksborgvej 399, DK-4000 Roskilde, Denmark \\ *Corresponding author: beltal@dtu.dk
}

\begin{abstract}
.
Electrophoretic deposition (EPD) is a promising method for coating complex shaped interconnects and contact components for solid oxide fuel cells and electrolyzers. In this work, we employ a combination of finite element modelling and experiments to assess the effect of substrate curvature on the fabrication of a $\mathrm{Mn}_{1.5} \mathrm{Co}_{1.5} \mathrm{O}_{4}$ coating by EPD. The coating is deposited on steel substrates machined to create a well-defined curvature and on a Crofer $22 \mathrm{H}$ steel grid. We find that post-deposition sintering of the coated steel substrate may lead to crack formation in concave surfaces, while a defect-free coating is achieved at convex surfaces. The formation of cracks is found to depend on a complex interplay between the coating thickness, the sintering procedure, and the substrate curvature radius. Oxidation testing in air at $750{ }^{\circ} \mathrm{C}$ showed that the $\mathrm{Mn}_{1.5} \mathrm{Co}_{1.5} \mathrm{O}_{4}$ coating reduced the oxidation rate of the Crofer $22 \mathrm{H}$ steel grid. Sintering the coating by a two-step reduction and re-oxidation procedure resulted in a more protective coating showing a greater tendency for crack healing compared to sintering the coating in air only.
\end{abstract}

Keywords: Solid oxide fuel cell; Interconnect; Finite element model; Electrophoretic deposition; Coating; Oxidation

\section{Introduction}

Solid oxide fuel cells (SOFC) enable efficient and clean conversion of chemical energy $\left(\mathrm{H}_{2}\right.$ containing fuels) into electrical energy and heat $[1,2]$. The same cells can be operated in electrolysis mode (SOEC) to convert steam into oxygen and hydrogen, thus providing a sustainable electrochemical energy storage solution [3,4]. Most recent solid oxide cell (SOC) stack designs include metallic interconnect plates made from ferritic stainless steel (FSS) [5-7]. The purpose of the interconnect is to provide an electrical contact between anode and cathode of two adjacent cells, as well as to separate the fuel gas from the oxidant. FSSs are attractive materials for this application due to their low cost and high formability enabling complex shaping [8-10].

To facilitate good distribution of the fuel/oxidant over each cell, removal of the reaction products, as well as a low pressure drop across the stack, the interconnect is fabricated with flow channels 
by e.g. milling or stamping. The flow-field design affects the distribution of the electrochemical reactions and thereby the temperature across the cell and stack [11]. In case of a poorly designed flow-field large temperature gradients may develop across the stack, resulting in thermal stresses and possibly failure due to thermal expansion mismatch between the brittle solid oxide cell and the other stack components [12]. Similarly, a stable electrical contact needs to be established between the cell and the interconnect in order to avoid "hot spots" of high local current density [13]. These challenges may be alleviated by using metallic meshes/grids for contacting the cell to the interconnect to ensure a good gas distribution below the current collection points. For the fuel side, Ni-based meshes may be used as suggested in [14,15]. For the oxidant side, FSS are more attractive due to the better oxidation resistance [16-18].

In order to prevent volatile $\mathrm{Cr}(\mathrm{VI})$ species from "poisoning" the oxygen electrode, and to reduce the growth rate of moderately conductive oxide scales, the FSS interconnect and contacting mesh should be coated [19-21]. ( $\mathrm{Mn}, \mathrm{Co})_{3} \mathrm{O}_{4}(\mathrm{MCO})$ spinel is a promising coating material, demonstrated to improve the FSS oxidation resistance, reduce $\mathrm{Cr}$ evaporation and provide a low area specific resistance $[22,23]$. The MCO coating can be readily applied using electrophoretic deposition (EPD), a process in which MCO particles suspended in a solution are deposited onto the interconnect by the application of an electric field. The process allows for fast deposition and good control of coating thickness [24]. EPD is less dependent on line-of-sight compared to other slurry-based methods such as spraying, sputtering and dip-coating [17], making it an attractive method for depositing MCO on complex shaped structures. Although the potential to coat a steel mesh by EPD has been demonstrated [25], most of the work on EPD of MCO coatings has been made on flat steel sheets [26-29].

Depositing the MCO coating by EPD (or any other powder-based method) requires a postdeposition sintering step in order to densify the coating. To avoid excessive oxidation of the underlying steel substrate, sintering should be carried out at the lowest possible temperature. Previous work has shown that a two-step sintering method, where the coating is first reduced to $\mathrm{MnO}$ and $\mathrm{Co}$ and then oxidized back to $(\mathrm{Mn}, \mathrm{Co})_{3} \mathrm{O}_{4}$, is most effective for achieving dense coatings at a moderate sintering temperature of $1000{ }^{\circ} \mathrm{C}[30,31]$. However, even a highly porous coating, resulting from sintering in air at $900{ }^{\circ} \mathrm{C}$, provides some protection against oxidation and Cr evaporation [22].

The coating density and sintering heat treatment can influence the coating/steel interface adhesion and consequentially, the likelihood of cracking and spallation. Akanda et al. [32] showed that a reduction and re-oxidation sintering procedure results in a stronger interface adhesion $\left(\sim 8 \mathrm{~J} / \mathrm{m}^{2}\right)$ compared a coating sintered in air only $\left(\sim 2 \mathrm{~J} / \mathrm{m}^{2}\right)$, due to a stronger reaction between the MCO coating and the Crofer 22 APU steel substrate. On the other hand, the air sintered coating was found to have a lower rate of tensile crack formation and thus a lower crack density. This was attributed to the weaker interface being less effective in transferring tensile stresses from the steel substrate to the coating $[32,33]$.

In this work, we use a combination of finite element modelling and experiments to provide new insight to the link between substrate curvature and cracks in coatings prepared by EPD, and how this in turn effects the oxidation resistance. The MCO coating is deposited both on model substrates with a well-defined curvature and on a steel grid. The protective effect of the fabricated coating is assessed by oxidation testing in air at $750{ }^{\circ} \mathrm{C}$. 


\section{Materials and methods}

\subsection{Sample preparation}

The suspension for electrophoretic deposition (EPD) was prepared using $\mathrm{Mn}_{1.5} \mathrm{Co}_{1.5} \mathrm{O}_{4}$ (MCO) powder from American Elements (mean particle size $0.36 \mu \mathrm{m}$, specific surface area $12.0 \mathrm{~m}^{2} / \mathrm{g}$ ). The powder was added to a 50/50 vol.\% mixture of ethanol (99\%) and isopropanol at $2 \mathrm{wt} . \%$ solid loading. Iodine $(0.5 \mathrm{~g} / \mathrm{L})$ was added as a dispersant. The suspension was milled using YSZ rods for $48 \mathrm{~h}$ before use. The EPD set-up consisted of a $150 \mathrm{ml}$ Teflon box and two $4 \times 4 \mathrm{~cm}^{2}$ plates of Crofer 22 APU servings as counter electrodes. The steel sample to be coated was mounted in parallel between the counter electrodes and deposition was carried out at $60 \mathrm{~V}$ for $60 \mathrm{~s}$ with the negative terminal connected to the sample.

For investigations on the effect of substrate curvature, a $1.5 \mathrm{~mm}$ thick sheet of Crofer 22 APU (Thyssen Krupp, VDM) was cut into $1 \times 3 \mathrm{~cm}^{2}$ samples. Trenches were milled into the samples applying different curvatures and resulting in $0.4 \mathrm{~mm}$ deep and $2 \mathrm{~mm}$ wide grooves. Before coating, the samples were washed in an ultrasonic cleaner for $10 \mathrm{~min}$ in acetone followed by 10 min in ethanol. EPD was carried out as described above. The coating was sintered in air at $900{ }^{\circ} \mathrm{C}$ for $2 \mathrm{~h}$ with $120^{\circ} \mathrm{C} / \mathrm{h}$ heating and cooling rate.

For studies of the oxidation kinetics, Crofer $22 \mathrm{H}$ grid (M-grid from Fiaxell SOFC Technologies) and a $0.3 \mathrm{~mm}$ thick sheet of Crofer $22 \mathrm{H}$ (Thyssen Krupp, VDM) were cut into $2 \times 2 \mathrm{~cm}^{2}$ samples. A $3 \mathrm{~mm}$ hole was punched into one edge of each sample for mounting purposes. The samples were washed in an ultrasonic cleaner for $10 \mathrm{~min}$ in acetone followed by $10 \mathrm{~min}$ in ethanol. EPD was carried out as described above. The coated samples were sintered either (a) in air at $900{ }^{\circ} \mathrm{C}$ for $4 \mathrm{~h}$ (denoted as $\mathrm{O} 900$ ), or (b) in $\mathrm{N}_{2}-9 \% \mathrm{H}_{2}$ at $1000{ }^{\circ} \mathrm{C}$ for $4 \mathrm{~h}$ followed by in air at $800{ }^{\circ} \mathrm{C}$ for $4 \mathrm{~h}$ (denoted as R1000).

\subsection{Characterization}

The surface area of the as-received Crofer $22 \mathrm{H}$ grid was determined by BET measurement using Krypton adsorption (Autosorb, Quantachrome Instruments).

Oxidation kinetics were studied by annealing coated and uncoated samples in air for a total of $2000 \mathrm{~h}$ at $750{ }^{\circ} \mathrm{C}$. Three samples of each type were suspended vertically in a chamber furnace (hanging on an alumina rod). The furnace was cooled to room temperature every $250 \mathrm{~h}$ and the samples were weighed on a scale with $0.1 \mathrm{mg}$ accuracy.

Microstructural characterization was performed using scanning electron microscopy (SEM, Zeiss Supra Field Emission SEM or Hitachi TM3000) and energy dispersive X-ray spectroscopy (EDX, Bruker). All EDX analysis was done at an acceleration voltage of $15 \mathrm{kV}$. For cross sectional characterization, samples were cold vacuum embedded in epoxy, ground and polished in successive steps down to $1 \mathrm{um}$. Multiple polishing steps were applied to inspect the grid along different planes. The curvature of the model substrate was determined by image analysis. 


\section{Modelling}

\subsection{Finite element modelling}

The stress level during sintering of the MCO coating is considered relatively low as fast diffusion processes (surface, grain-boundary, bulk) allow for the sintering body to deform at high rate, see e.g. [34-36]. Nevertheless, sintering stresses may still provoke crack propagation if the surface minimizing mechanism (sintering) is overcome by the surface generating mechanism (crack propagation) [37].

To evaluate the stresses during sintering of the MCO coating, a plain strain 2D finite element model (FEM) of the coated interconnect cross section was built using Comsol Multiphysics 5.3. A comprehensive model of the coating sintering process requires a substantial amount of material parameters, which are circumstantial to measure, see e.g. [34-36]. Therefore, a simplified model is used to evaluate stress variation as a function of geometrical variations and thereby provide a means to qualitatively explain the failures observed experimentally. For this purpose, the stresses at different curvatures are normalized with respect to the stresses at a flat continuous surface. The stress field due to the sintering strain is here investigated elastically. Although the deformations through sintering are primarily driven by viscous flow (diffusion mechanisms), the stresses during sintering may still be released elastically by the propagation of a crack [37].

The geometry of the FEM is shown in Figure 1. Two types of cracks were modelled; one at the convex curvature and one at a flat surface. To increase accuracy while limiting computational cost, the radial zones (see Fig. 1b) around each crack were modelled with a higher mesh density compared to the region outside these zones (see Fig. 1c). The length of the finite elements in the vicinity of the crack is approximately $1 \mu \mathrm{m}$.

a)

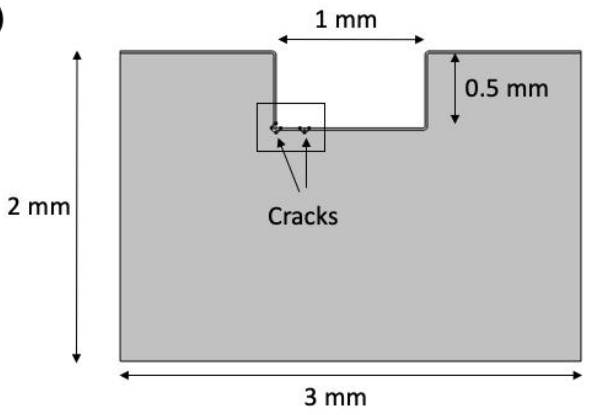

b)

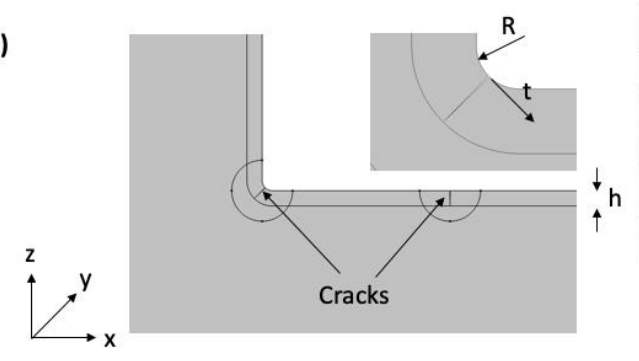

c)

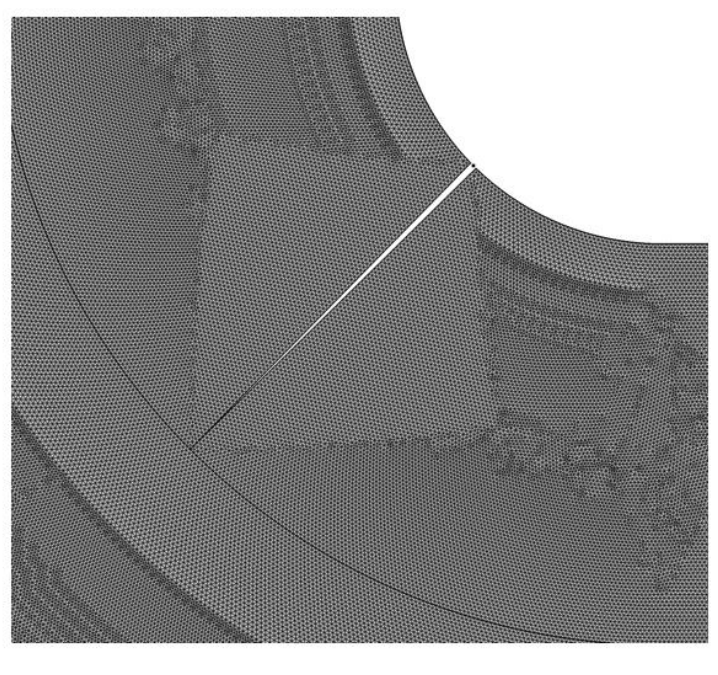

Figure 1. Geometry of the interconnect, location of modelled cracks and coordinate systems used in the FEM. a) overview and b) zoomed view of the boxed area in fig. a). The circles around the cracks indicate areas where a higher mesh density was used, c) illustration of the mesh density used around the crack in the model. 
As the steel substrate is much stiffer than the coating, the contraction of the coating during sintering will not be able to bend the cut-out of the steel substrate in the model. This is modelled by constraining the vertical displacements on the lower boundary to zero. As the cut-out is of a repeating geometry, the vertical boundaries will not be able to rotate, therefore, the horizontal displacement of the left side of the geometry is constrained to zero as well. The right hand side is left free to move to avoid generating an external stress on the geometry from the sintering strain and the thermal expansions.

The stress field develops similarly in case of the convex and the flat surface. To demonstrate this, the maximum principle stress at the convex and the concave corners was investigated first as a function of the curvature and coating thickness. Secondly, the maximum stress at the crack tip for a crack propagating through the coating is determined at a convex corner and at a flat surface. This allows for a qualitative description of the critical parameters that should be controlled in order to avoid crack propagation.

\subsection{Criteria for crack propagation}

To avoid crack propagation, the local energy release rate at the crack front $G^{e q}$ must remain below the critical energy release rate of the MCO coating $G_{c}$. Hutchinson and Suo [38] showed that the steady state average energy release rate, $G_{s s}^{e q}$, for a crack propagating through a thin film in equi-biaxial stress can be described by

$G_{S S}^{e q}=\frac{\pi}{2}(1.1215)^{2} \frac{(1-v)^{2} \sigma^{2} h}{E}$

where $\sigma$ is the equi-biaxial stress, $h$ the thickness of the film, $v$ the Poisson's ratio of the film and $E$ the elastic stiffness of the film. The local energy release rate at the crack front $G^{e q}$ is a factor $\left(f_{l}\right)$ higher than the energy release rate in steady state, $G_{s s}^{e q}$, i.e. $G^{e q}=f_{l} G_{s s}^{e q}$.

At the flat part of the coating the stress along the plane, $\sigma_{x}$, equals that into the plane $\sigma_{y}$ (equibiaxial stress). The stress at the curvature tangent, $\sigma_{t}$, differs in the plane, but not out of plane. The difference between $\sigma_{t}$ and $\sigma_{y}$ will be described by the factor $f_{\sigma}$, where $\sigma_{t}=f_{\sigma} \sigma_{y}$. The strain along the curvature tangent can then be described as $\varepsilon_{t}=\left(\sigma_{t}-v \sigma_{y}\right) / E=\sigma_{y}\left(f_{\sigma}-v\right) / E$, and the steady state energy release rate in the curvature becomes

$G_{S S}^{t}=\frac{\pi}{2}(1.1215)^{2} \frac{\left(f_{\sigma}-v\right)^{2} \sigma^{2} h}{E}$

Notice that also here the energy release rate scales with the thickness of the coating, $h$.

The local energy release rate in the curvature, $G^{t}$, relates to the steady state energy release rate $G_{s S}^{t}$ with a factor of $f_{l}$, i.e. $G^{t}=f_{l} G_{s s}^{t}$. By combining the above equations, it may be shown that the relation between the local energy release rate at the flat surface and at the curvature is given by:

$f_{G}=\frac{G^{t}}{G^{e q}}=\frac{f_{l} G_{s s}^{t}}{f_{l} G_{s s}^{e q}}=\frac{\left(f_{\sigma}-v\right)^{2}}{(1-v)^{2}}$ 
Accordingly, the energy release rate scales linearly with the thickness of the coating (Eq. (2)) and with the curvature factor $\left(f_{\sigma}-v\right)^{2} /(1-v)^{2}$ (Eq. (3)). This analysis shows that the two parameters $f_{\sigma}$ and $f_{G}$ are almost independent of the material parameters of the interconnect and the coating. Only $f_{G}$ depends on the Poisson's ratio of the coating, $v$.

For the simulations in this work, the material parameters of Crofer $22 \mathrm{APU}$ at $800{ }^{\circ} \mathrm{C}$ are used for the interconnect $(\mathrm{E}=75 \mathrm{GPa}, v=0.3$ ) [39]. For the MCO coating a low Young's modulus (1 GPa) is used and the Poisson's ratio for the porous sintering body is estimated to 0.25 based on the Skorohod Olevsky Viscous Sintering theory [34,40]. However, as pointed out above, due to the normalization with respect to the stress in the planar regions, the results are independent of the interconnect material parameters and the Young's modulus of the coating.

\section{Results and discussion}

\subsection{Effect of curvature for electrophoretic deposition}

Figure 2 shows SEM cross sectional images of the MCO coating deposited on a Crofer 22 APU substrate with milled trenches. After sintering at $900{ }^{\circ} \mathrm{C}$ in air a crack was formed at the concave corner (stippled circle in Fig. 2), while the convex corner appeared to be defect free. Inspecting several micrographs where the substrate curvature varied revealed that, generally, cracks were formed at concave corners characterized by a fillet radius below $40 \pm 5 \mu \mathrm{m}$, while a nearly defectfree MCO coating was formed at concave corners with a radius above $85 \pm 5 \mu \mathrm{m}$.. In addition, no defects were observed at convex corners with a fillet radius as low as $2.5 \pm 2 \mu \mathrm{m}$. In the following section, these observations are explained by finite element modelling of the mechanical stresses in the coating.

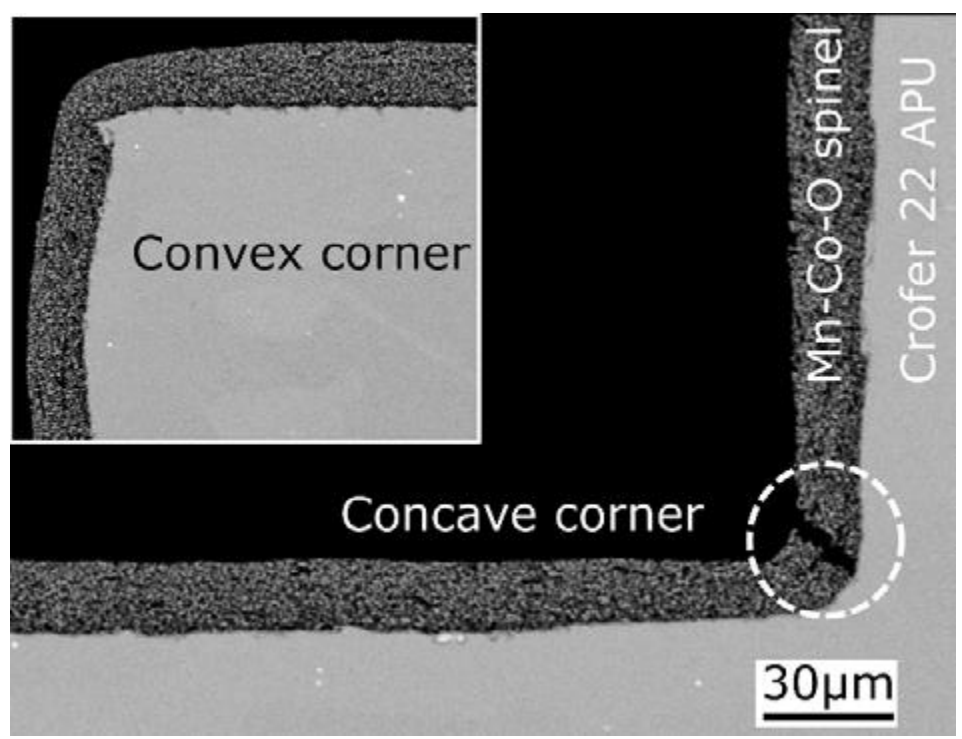

Figure 2. SEM cross sectional image of MCO coated Crofer 22 APU after sintering. The MCO coating is cracked where the steel surface is concave, but remains intact in the convex corner. 


\subsection{Finite element model}

In Figure 3 the ratio between the maximum stress in the curvature and on a flat part of the coating, $f_{\sigma}$, is plotted as a function of the curvature radius, $R$, and the coating thickness, $h$. The results show that relative to a flat surface, the stresses are smaller at the convex curvatures and larger in the concave curvatures. The inserts at the top and bottom right hand side in Figure 3 illustrates the distribution of the first principle stresses at the concave and convex curvatures in the coating, respectively. In both cases, it is seen that the stresses are distributed relatively evenly across the coating thickness. The highest stress is found at the center of the concave curvature. From this, the stresses decrease continuously along the curvature towards the flat part of the coating. As the curvature radius $(\mathrm{R})$ of the concave surface decreases, the stresses increase at a high rate, particularly in the interval between $10 \mu \mathrm{m}$ to $20 \mu \mathrm{m}$. Figure 3 also shows that as the coating thickness $(\mathrm{h})$ increases, the stress concentration at the concave surface also increases.

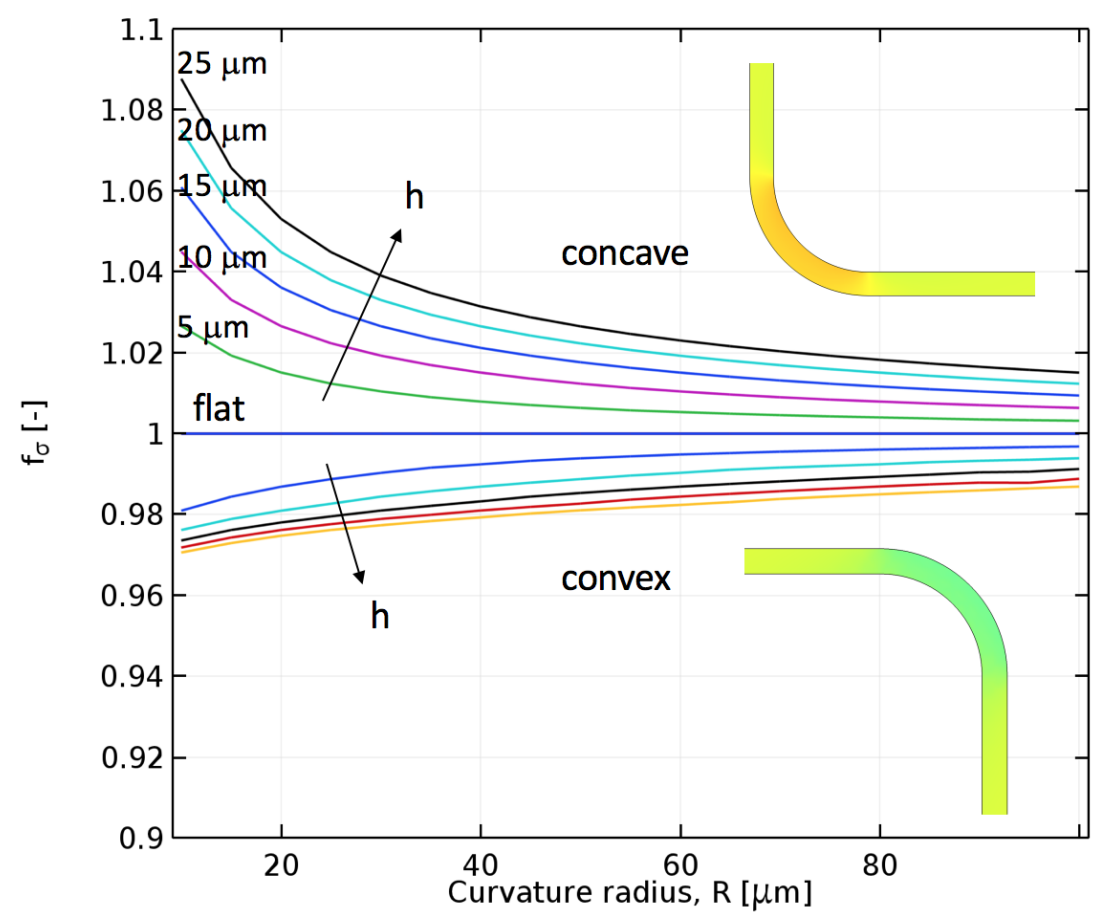

Figure 3. Ratio between the maximum stress in the curvature and the stress on a flat part of the coating, $f_{\sigma}$, as a function of the curvature radius, $R$, and coating thickness, $h$. Right hand side insert figures show the relative stress distribution according to the FEM, where orange indicates a relatively larger stress and green indicates a relatively lower stress.

In the deposition trial (see section 4.1) cracks were observed in concave corners with a fillet radius below $40 \pm 5 \mu \mathrm{m}$. Figure 3 shows that for a $20 \mu \mathrm{m}$ thick coating at a curvature of $30 \mu \mathrm{m}$ the stress in the curvature is $3.3 \%$ higher than that in the flat part of the coating. Although the 
stresses in the curvature are not significantly higher, the energy release rate, $G$, increases at an even higher rate for low curvature radii according to Eq. (3). This can be seen in Figure 4, where the ratio between the energy release rates for a crack propagating at the concave curvature relative to that in a flat part of the coating, $f_{\mathrm{G}}$, is plotted. For the same curvature radius and coating thickness, the energy release rate factor, which determines the failure, is significantly higher than the stress factor (cf. Fig. 3). For the $20 \mu \mathrm{m}$ thick coating at a curvature of $30 \mu \mathrm{m}$, the energy release rate is $8.0 \%$ higher at the curvature than in the flat part of the coating. Figure 4 also shows that as the curvature radius is increased to above $80 \mu \mathrm{m}$ the energy release rate in the curvature becomes almost the same as that in the flat part of the coating. This is also consistent with the experimental findings presented in Section 4.1. Based on these results, we suggest that in order to prevent cracking in a $20 \mu \mathrm{m}$ thick MCO coating, the gas channel grooves should be produced with a fillet radius above $80 \mu \mathrm{m}$.

As the crack propagates, the stress field will change, mostly due to changes in the stress concentration at the crack tip. However, as the stiffness of the coating during sintering is much smaller than the stiffness (and thickness) of the solid interconnect, the redistribution of stresses during crack propagation will be minimal. To illustrate, the maximum first principle stress at the crack tip in the concave curvature and in the flat part of the coating is shown as a function of crack depth in Figure 5. This shows that due to the limited stress redistribution, the stresses during crack propagation are nearly constant. Accordingly, it is reasonable to use the same analysis for crack propagation in the curvature as in the flat parts, resulting in Eq. (3). Figure 5 also shows that the stress concentration at the crack tip is $\sim 30$ to $50 \%$ higher for a concave curvature relative to a flat surface.

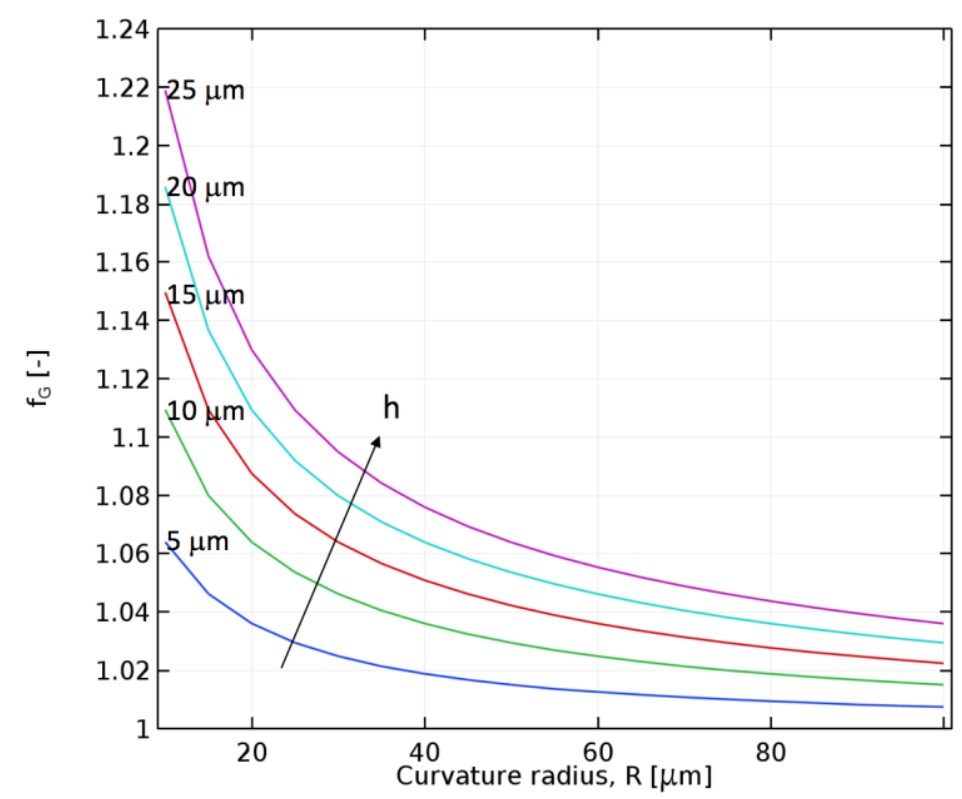

Figure 4. Ratio between the energy release rate for a crack propagating in the concave curvature and the energy release rate for a crack propagating in the flat part of the coating, $f_{G}$, plotted as a function of the curvature radius, $R$, and the coating thickness, $h$. 


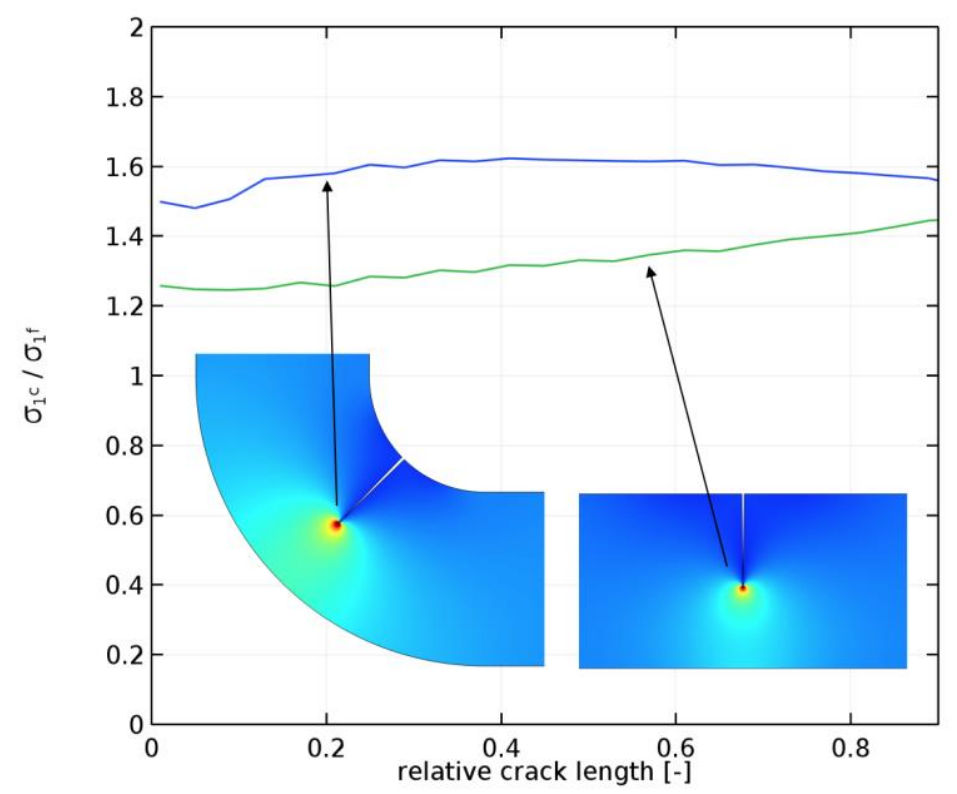

Figure 5. Maximum first principle stress at the tip of the cracks $\sigma_{1}^{c}$ in the concave curvature and in the flat part of the coating as a function of crack length. The stress is normalized with the first principle stress in the uncracked flat part of the coating $\sigma_{1}^{f}$ and the crack depth is normalized with the coating thickness at the two locations.

\subsection{Electrophoretic deposition on Crofer M-grid}

For evaluation of the protective effect of the $\mathrm{Mn}_{1.5} \mathrm{Co}_{1.5} \mathrm{O}_{4}$ coating produced by EPD, the coating was deposited on a Crofer $22 \mathrm{H}$ steel grid. A SEM image of the as-received Crofer M-grid is shown in Figure 6a. The grid opening was $\sim 0.75 \times 0.25 \mathrm{~mm}^{2}$ and the grid was $0.2 \mathrm{~mm}$ thick at the highest point. The surface had clear signs of deformation from the shaping process and a high surface roughness. The M-grid surface area was $41 \mathrm{~cm}^{2} / \mathrm{g}$ according to BET measurements (average of two measurements using $6.5 \mathrm{~g}$ material, correlation coefficient 0.997 ).

The MCO coated M-grid was sintered either in air at $900{ }^{\circ} \mathrm{C}(\mathrm{O} 900$ samples $)$ or in $\mathrm{N}_{2}-\mathrm{H}_{2}$ at $1000{ }^{\circ} \mathrm{C}$ followed by in air at $800{ }^{\circ} \mathrm{C}$ (R1000 samples). SEM images of the sample surface after each heat treatment are shown in Figure $6 \mathrm{~b}$ and $6 \mathrm{c}$, respectively. The R1000 heat treatment resulted in a denser coating compared to the $\mathrm{O} 900$ heat treatment, in accordance with previous results, where a $\mathrm{MnCo}{ }_{1.7} \mathrm{Fe}_{0.3} \mathrm{O}_{4}$ coating was deposited and sintered on Crofer 22 APU sheet samples [22] . During the two-step R1000 sintering procedure, the $\mathrm{Mn}_{1.5} \mathrm{Co}_{1.5} \mathrm{O}_{4}$ coating was first reduced to $\mathrm{MnO}$ and Co particles, and subsequently re-oxidized to the spinel phase [30]. The enhanced densification obtained by this sintering procedure can be explained by a reaction-type sintering mechanism [30].

As can be observed from Figure 6, EPD led to successful coating coverage on the entire M-grid surface, despite the complex geometry and high roughness of the grid. However, cracks in the coating appeared after sintering. Such severe cracking is typically not observed when the coating is deposited and sintered on flat sheet samples [22]; thus, the cracks may be attributed to the 
curvature or roughness of the M-grid. The high roughness and surface irregularity of the asreceived M-grid made it difficult to determine the exact curvature in the cracked areas.

Nevertheless, it is clear that the crack density is highest close to the grid opening and that very few crack form the top points. Ignoring the surface roughness (micro-curvature), the grid opening corresponds to a concave surface while the top points correspond to a convex surface. Thus, the result of depositing MCO on a complex shaped component as the M-grid are in good agreement with the modelling results, showing that the stress concentration, and therefore the probability of cracking, is highest in concave parts.

From Figure 6 it is also evident that the width of the cracks on the 0900 sample surface $(3-4 \mu \mathrm{m})$ was significantly more narrow compared to the width of the cracks on the R1000 sample surface $(25-30 \mu \mathrm{m})$. The area density of cracks was also higher in case of the latter sample. Considering the greater density of the R1000 coating, these observations point to that the cracks were formed due to the sintering shrinkage. Our observations are consistent with the results from Akanda et al. $[32,33]$ showing that a denser coating (produced by two-step sintering) has a higher rate of tensile crack formation and a higher crack density than a more porous coating (sintered in air).
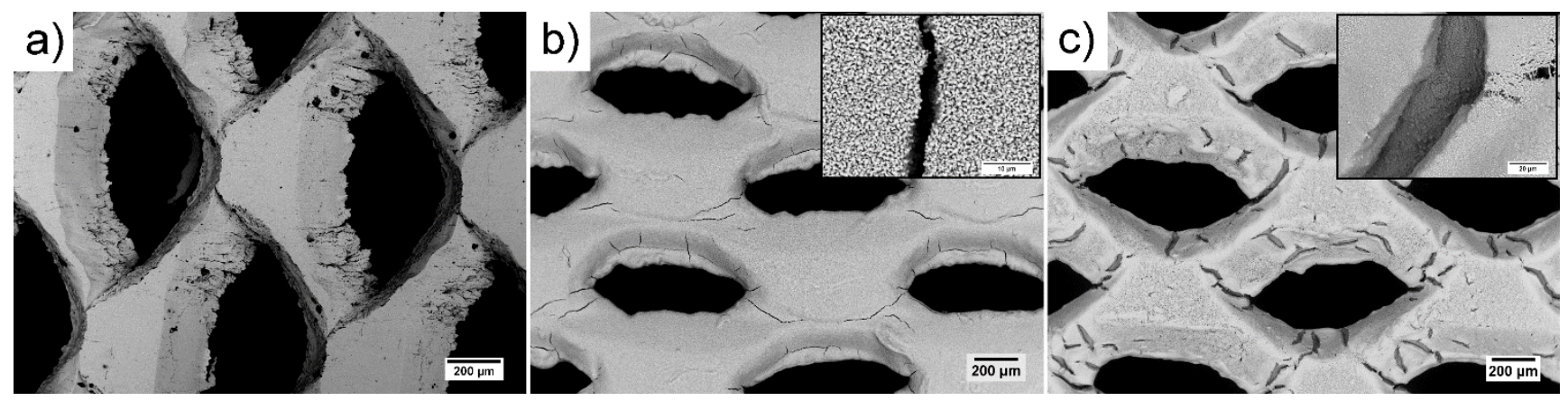

Figure 6. SEM surface micrographs a) As-received Crofer M-grid. b) $\mathrm{Mn}_{1.5} \mathrm{Co}_{1.5} \mathrm{O}_{4}$ coated and $\mathrm{O} 900$ heat treated, c) $\mathrm{Mn}_{1.5} \mathrm{Co}_{1.5} \mathrm{O}_{4}$ coated and $\mathrm{R} 1000$ heat treated. The high magnification images in the insets of $b$ and $c$ display typical cracks observed on the coating surface.

\subsection{Oxidation of $\mathrm{Mn}_{1.5} \mathrm{Co}_{1.5} \mathrm{O}_{4}$ coated M-grid}

The mass gain of bare and $\mathrm{Mn}_{1.5} \mathrm{Co}_{1.5} \mathrm{O}_{4}$ coated Crofer M-grid during oxidation in air at $750{ }^{\circ} \mathrm{C}$ is shown in Figure 7. The results are normalized according to the surface area of the uncoated Mgrid determined by BET $\left(41 \mathrm{~cm}^{2} / \mathrm{g}\right)$. The mass change of bare Crofer $22 \mathrm{H}$ (flat samples cut from a $0.3 \mathrm{~mm}$ thick sheet) is included as a reference. For Crofer $22 \mathrm{H}$, the surface area is taken as the geometrically measured surface area, i.e. any surface roughness is not accounted for. Figure 7 shows that during the first $1000 \mathrm{~h}$ of oxidation, the mass gains of uncoated M-grid and Crofer 22 $\mathrm{H}$ were nearly the same. From 1000 to $2000 \mathrm{~h}$ of oxidation, the mass of Crofer $22 \mathrm{H}$ increased slightly faster than the mass of the M-grid. The lower oxidation rate of the M-grid could have been due to the larger surface area, leading to a higher rate of Cr-vaporization and accordingly a lower net mass gain [41]. 
The mass gain measurements show that the $\mathrm{Mn}_{1.5} \mathrm{Co}_{1.5} \mathrm{O}_{4}$ coating decreased oxidation of the $\mathrm{M}$ grid (Fig. 7). After $2000 \mathrm{~h}$ oxidation at $750{ }^{\circ} \mathrm{C}$, the absolute mass gain of the M-grid was reduced by $17 \%$ with the $\mathrm{O} 900$ sintered coating, and by $76 \%$ with the R1000 sintered coating. Based on the slope of the mass gain curve, it appears that only the denser R1000 sintered coating provided a reduction in the oxidation rate, despite the fact that the R1000 coating was covered by a greater number of cracks than the $\mathrm{O} 900$ coating (see Fig. 6). These results are in agreement with studies of the effect of coating density on $\mathrm{MnCo} 1.7 \mathrm{Fe}_{0.3} \mathrm{O}_{4}$ coated Crofer $22 \mathrm{APU}$ (sheet), where similar sintering procedures were compared [22]. In addition to providing better oxidation resistance, a denser coating has been shown to be more effective in reducing Cr evaporation from ferritic stainless steels $[22,42]$.

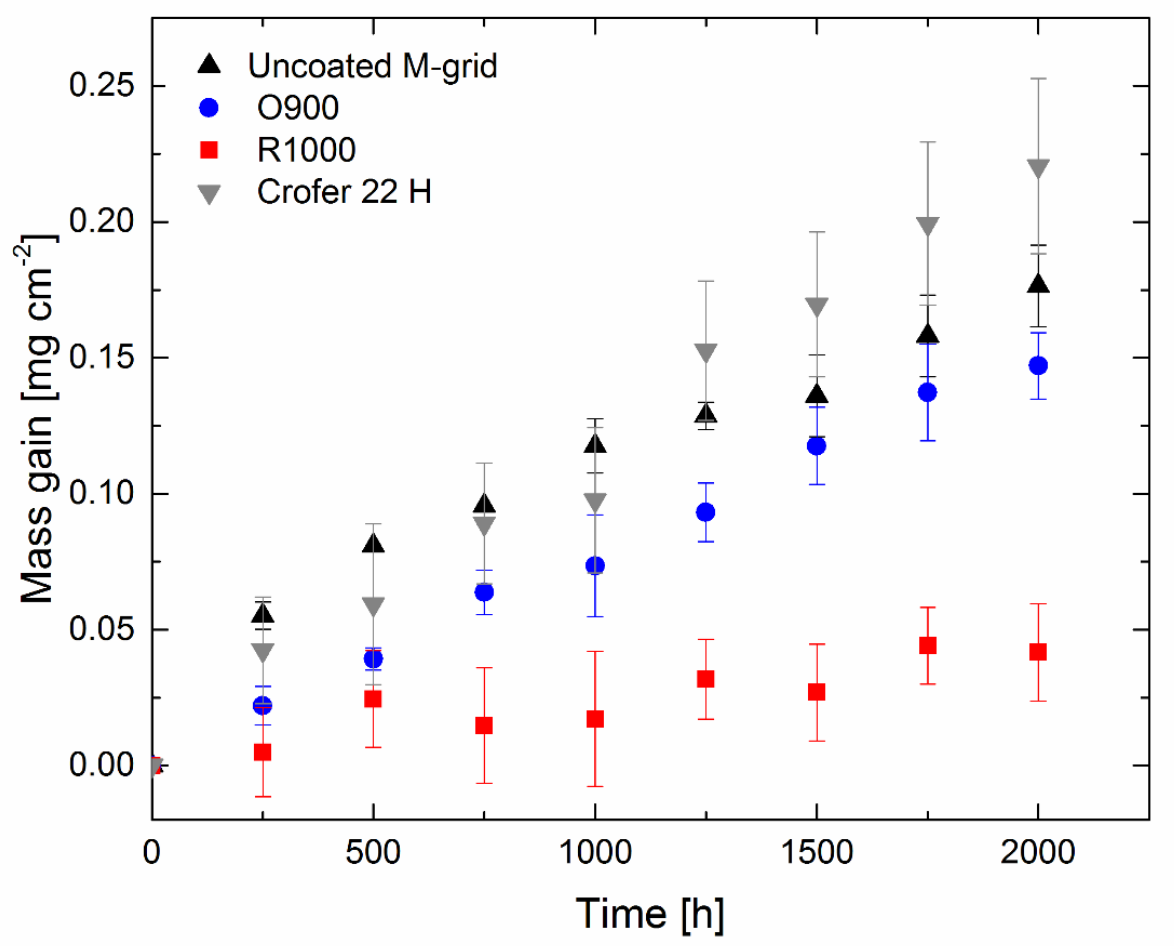

Figure 7. Mass gain measured during oxidation in air at $750{ }^{\circ} \mathrm{C}$. Each point is average of three samples with error bars showing the standard deviation.

\subsection{SEM characterization after oxidation}

\subsubsection{Uncoated steel grid}

SEM images of the surface and cross-section of the uncoated M-grid sample after $2000 \mathrm{~h}$ oxidation at $750{ }^{\circ} \mathrm{C}$ are shown in Figure $8 \mathrm{a}$. The thermally grown oxide scale consisted primarily of an inner Cr-rich oxide and an outer $\mathrm{Mn}$ and $\mathrm{Cr}$-rich oxide according to EDX analysis. Based on previous investigations of oxidized Crofer $22 \mathrm{H}$, these oxides are most likely $\mathrm{Cr}_{2} \mathrm{O}_{3}$ and $(\mathrm{Mn}, \mathrm{Cr})_{3} \mathrm{O}_{4}$, respectively $[43,44]$. The oxide scale thickness varies greatly along the sample from ca. $0.5 \mu \mathrm{m}$ to ca. $11 \mu \mathrm{m}$, with overall thicker scales observed where the grid substrate is thinner 
and the alloy surface has a higher roughness according to the cross-sectional SEM images. In areas where the substrate is very thin, thick Fe-rich oxides were formed (see circled area in Figure 8a). The formation of Fe-oxides can be attributed to local depletion of $\mathrm{Cr}$ from the underlying substrate, which will be more rapid in thinner sections of the grid $[41,45]$. The average oxide scale thickness on the uncoated $\mathrm{M}$-grid was measured to $2.1 \mu \mathrm{m}$, considering only the $\mathrm{Cr}_{2} \mathrm{O}_{3}$ and $(\mathrm{Mn}, \mathrm{Cr})_{3} \mathrm{O}_{4}$ oxides. The bright precipitates in the alloy are rich in $\mathrm{Si}$ and $\mathrm{Nb}$ according to EDX analysis, and have previously been identified as Laves phases [46,47].

a) Uncoated M-grid
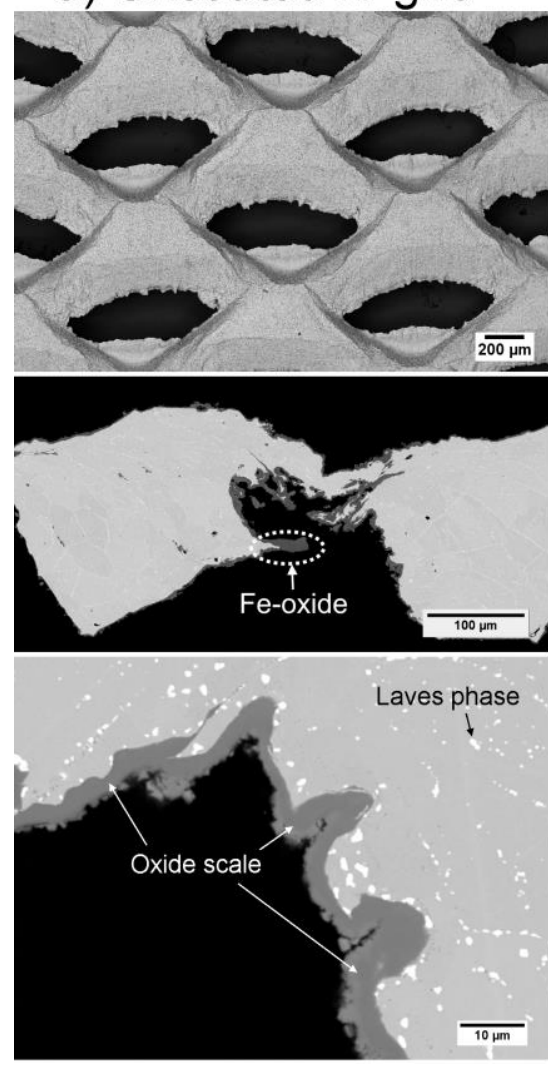

b) 0900 coated
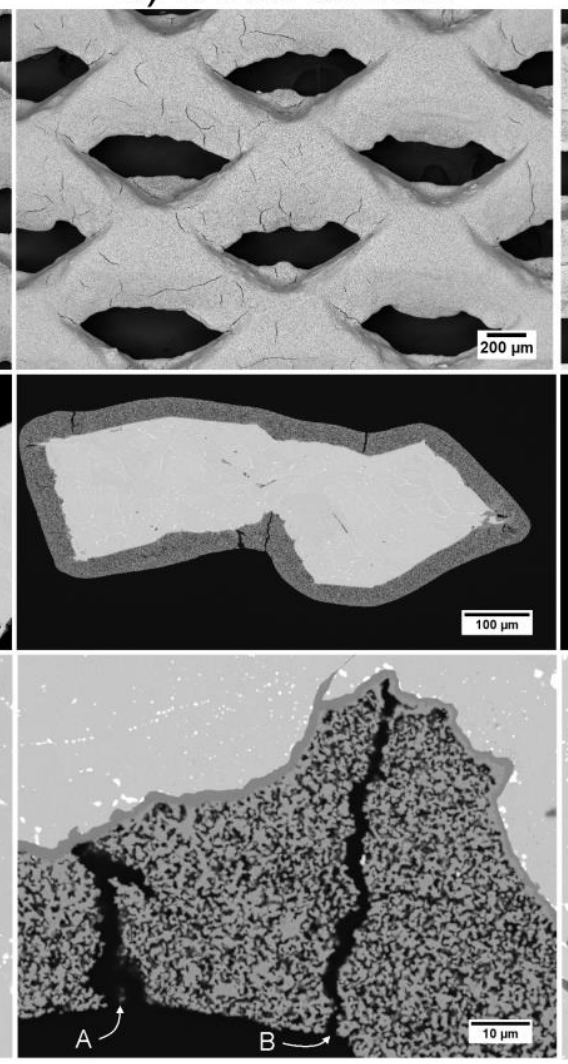

c) R1000 coated

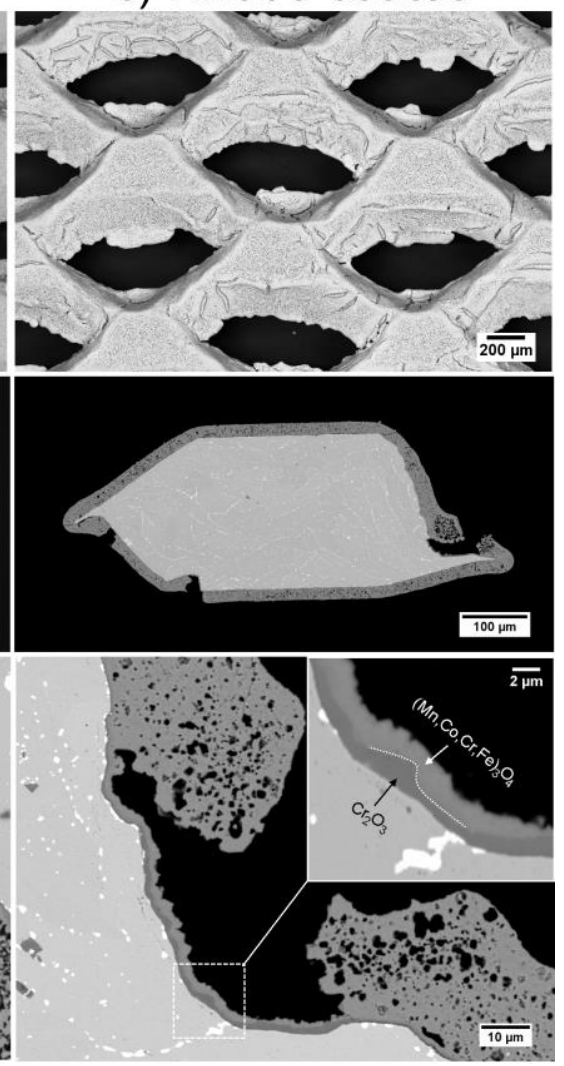

Figure 8. SEM images of uncoated and $\mathrm{Mn}_{1.5} \mathrm{Co}_{1.5} \mathrm{O}_{4}$ coated $\mathrm{M}$-grid after $2000 \mathrm{~h}$ oxidation at 750 ${ }^{\circ} \mathrm{C}$. a) Uncoated M-grid, b) $\mathrm{Mn}_{1.5} \mathrm{Co}_{1.5} \mathrm{O}_{4}$ coated, sintered $\mathrm{O} 900$, c) $\mathrm{Mn}_{1.5} \mathrm{Co}_{1.5} \mathrm{O}_{4}$ coated, sintered R1000

\subsection{2 $\mathrm{Mn}_{1.5} \mathrm{Co}_{1.5} \mathrm{O}_{4}$ coated steel grid sintered in air}

SEM images of the 0900 sample after oxidation are shown in Figure 8b. The variation in oxide scale thickness was smaller compared to variation on the uncoated M-grid. Furthermore, the oxide scale consisted primarily of $\mathrm{Cr}_{2} \mathrm{O}_{3}$ and no Fe-rich oxides could be observed. The average oxide scale thickness measured on $\mathrm{O} 900$ samples after $2000 \mathrm{~h}$ oxidation at $750{ }^{\circ} \mathrm{C}$ was $1.3 \mu \mathrm{m}$, which is $60 \%$ lower than the oxide scale measured on the uncoated M-grid. Thus, the cross 
sectional analysis shows that the 0900 sintered coating provided a greater protection against oxidation than indicated by the mass change measurement.

Cracks observed after coating sintering of the 0900 sample were still present after $2000 \mathrm{~h}$ of oxidation at $750{ }^{\circ} \mathrm{C}$. Two types of cracks could be distinguished, highlighted as $\mathrm{A}$ and $\mathrm{B}$ in Figure $8 \mathrm{~b}$. Crack $\mathrm{A}$ is ca. $3.5 \mu \mathrm{m}$ wide and extends all the way from coating surface to the thermally grown oxide scale on the alloy, leaving the oxide scale exposed to the atmosphere. The $\mathrm{Cr}$ evaporation from such areas is expected to be the same as for uncoated Crofer $22 \mathrm{H}$. Crack B is more narrow (ca $2.5 \mu \mathrm{m}$ wide) and the thermally grown oxide scale at the crack tip is covered by a thin layer of the coating material (i.e. $\mathrm{Mn}_{1.5} \mathrm{Co}_{1.5} \mathrm{O}_{4}$ ). This thin coating layer is visible by its slightly brighter contrast compared to the oxide scale. The oxide scale is visibly thinner $(0.7-1$ $\mu \mathrm{m})$ in vicinity of crack B compared to the oxide scale in vicinity of crack A (1.5-1.7 $\mu \mathrm{m})$. It should be pointed out that the oxide scale varied significantly in thickness $(0.4 \mu \mathrm{m}$ to $3.4 \mu \mathrm{m})$ also in areas far away from any cracks, making it difficult to conclude whether the observed differences can be attributed to the crack width. Nevertheless, the thin coating layer in the narrow crack likely contributed to limit the growth of the oxide scale.

\subsection{2 $\mathrm{Mn}_{1.5} \mathrm{Co}_{1.5} \mathrm{O}_{4}$ coated steel grid sintered by reduction and re-oxidation procedure}

SEM images of the R1000 sample after oxidation are shown in Figure 8c. The coating was highly dense and there was almost no percolation between the remaining pores, indicating that the coating provided good protection against the oxidizing atmosphere. The thermally grown oxide scale under the R1000 coating was significantly thinner than under the more porous 0900 coating. On average, the oxide scale was $0.6 \mu \mathrm{m}$ thick, or $250 \%$ lower than for the uncoated Mgrid. According to EDX analysis, there was greater interdiffusion of $\mathrm{Co}$ and $\mathrm{Cr}$ at the oxide scale/coating interface of the R1000 sintered samples compared to the O900 sintered samples. This is visible as a lower contrast at this interface in the backscatter detector images in Fig. 8c. It has been shown previously that $\mathrm{Co}$ and $\mathrm{Cr}$ interdiffusion at the oxide scale/coating interface is more pronounced for spinel coatings sintered by a two-step reduction and re-oxidation procedure, compared to coatings sintered in air only [22]. During the reduction heat treatment, the coating is reduced to $\mathrm{MnO}$ and $\mathrm{Co}$ and the primary oxidation product on the steel surface is $(\mathrm{Mn}, \mathrm{Cr})_{3} \mathrm{O}_{4}$ [30]. During re-oxidation, Co diffuses into the $(\mathrm{Mn}, \mathrm{Cr})_{3} \mathrm{O}_{4}$ layer to form $(\mathrm{Mn}, \mathrm{Co}, \mathrm{Cr})_{3} \mathrm{O}_{4}$.

The cracks observed after the R1000 sintering procedure were still present after $2000 \mathrm{~h}$ oxidation at $750{ }^{\circ} \mathrm{C}$. However, even in the widest cracks of the R1000 coating the thermally grown oxide scale was covered by a continuous, dense layer having a similar composition as the coating, with additional 4-10 wt.\% of Cr and 2-4 wt.\% of Fe (according to EDX analysis). The formation of this intermediate layer indicates a form of "crack healing" by a combination of Co and Mn surface diffusion and $\mathrm{Cr}$ and Fe diffusion from the alloy. Similar crack healing has been reported previously in case of submicron thick Co-coatings, which transform to $\mathrm{Co}_{3} \mathrm{O}_{4}$ and $(\mathrm{Mn}, \mathrm{Co})_{3} \mathrm{O}_{4}$ upon oxidation and outward diffusion of Mn from the alloy [48,49]. Falk-Windisch et al. [48] reported that cracks up to $4 \mu \mathrm{m}$ in width were covered by Co and $\mathrm{Mn}$ after $24 \mathrm{~h}$ annealing in air at $850{ }^{\circ} \mathrm{C}$ due to cation surface diffusion. Crack healing has also been observed for coatings prepared by atmospheric plasma spraying, where it was attributed to the phase transformation from a meta-stable $(\mathrm{Mn}, \mathrm{Co}, \mathrm{Fe}) \mathrm{O}$ rock salt structure to a $(\mathrm{Mn}, \mathrm{Co}, \mathrm{Fe})_{3} \mathrm{O}_{4}$ spinel structure [50]. Here, the greater tendency for crack healing in case of the R1000 coating compared to the O900 
coating is likely due to the higher cation mobility when the coating was reduced to $\mathrm{MnO}$ and $\mathrm{Co}$ during the first step of the sintering procedure. Thus, for the R1000 coating the "self-healing" can be attributed to a combination of cation inter-diffusion and the volume expansion taking place when the coating is re-oxidized to a spinel.

\section{Conclusion}

This work has demonstrated that electrophoretic deposition (EPD) is a promising method for coating complexly shaped steel components such as solid oxide cell interconnects and contacting meshes/grids. However, post-deposition sintering of coated parts may lead to crack formation at concave surfaces.

Finite element modelling was employed to describe how the maximum stress and energy release rate from the cracking depends on the curvature radii and coating thicknesses. The model showed that the stress concentration, and therefore likelihood of cracking, is larger at concave surfaces compared to flat and convex surfaces, in consistence with experimental observations. Based on the findings we suggest that interconnect gas channel grooves should be produced with a fillet radius larger than $85 \mu \mathrm{m}$ in order to avoid cracking in a $\sim 20 \mu \mathrm{m}$ thick oxide coating.

Mass gain measurements showed that a $\mathrm{Mn}_{1.5} \mathrm{Co}_{1.5} \mathrm{O}_{4}$ coating deposited by EPD effectively improves the oxidation resistance of Crofer M-grid in air at $750{ }^{\circ} \mathrm{C}$ over the first $2000 \mathrm{~h}$. Sintering the coating by a reduction and re-oxidation procedure produced a denser and more protective coating compared to sintering in air only. Both sintering methods resulted in crack formation at concave surfaces during sintering. The reduced and re-oxidized coating showed greater tendency for crack healing during subsequent aging in air.

\section{Funding}

This research did not receive any specific grant from funding agencies in the public, commercial, or not-for-profit sectors. 


\section{References}

[1] B.C.H. Steele, A. Heinzel, Materials for fuel-cell technologies, Nature. 414 (2001) 345-352. doi:10.1038/35104620.

[2] P. Singh, N.Q. Minh, Solid Oxide Fuel Cells: Technology Status, International Journal of Applied Ceramic Technology. 1 (2004) 5-15. doi:10.1111/j.1744-7402.2004.tb00149.x.

[3] C. Graves, S.D. Ebbesen, M. Mogensen, K.S. Lackner, Sustainable hydrocarbon fuels by recycling $\mathrm{CO} 2$ and $\mathrm{H} 2 \mathrm{O}$ with renewable or nuclear energy, Renewable and Sustainable Energy Reviews. 15 (2011) 1-23. doi:10.1016/j.rser.2010.07.014.

[4] S.H. Jensen, C. Graves, M. Mogensen, C. Wendel, R. Braun, G. Hughes, Z. Gao, S.A. Barnett, Large-scale electricity storage utilizing reversible solid oxide cells combined with underground storage of CO2 and CH4, Energy Environ. Sci. 8 (2015) 2471-2479. doi:10.1039/C5EE01485A.

[5] L. Blum, U. Packbier, I.C. Vinke, L.G.J. de Haart, Long-Term Testing of SOFC Stacks at Forschungszentrum Jülich, Fuel Cells. 13 (2013) 646-653. doi:10.1002/fuce.201200151.

[6] Y. Naumovich, M. Błesznowski, A. Żurawska, Contemporary Approaches to Planar SOFC Stack Design and Performance Characterization, in: J. Kupecki (Ed.), Modeling, Design, Construction, and Operation of Power Generators with Solid Oxide Fuel Cells: From Single Cell to Complete Power System, Springer International Publishing, Cham, 2018: pp. 49-96. doi:10.1007/978-3-319-75602-8_3.

[7] D. Hickey, M. Alinger, A. Shapiro, K. Brown, T. Striker, H. Wang, S. Gaunt, D. Kinsey, I. Hussaini, Stack Development at GE-Fuel Cells, ECS Trans. 78 (2017) 107-116. doi:10.1149/07801.0107ecst.

[8] S. Linderoth, P.V. Hendriksen, M. Mogensen, N. Langvad, Investigations of metallic alloys for use as interconnects in solid oxide fuel cell stacks, Journal of Materials Science. 31 (1996) 5077-5082. doi:10.1007/BF00355908.

[9] P. Kofstad, R. Bredesen, High temperature corrosion in SOFC environments, Solid State Ionics. 52 (1992) 69-75. doi:10.1016/0167-2738(92)90092-4.

[10] J.W. Fergus, Metallic interconnects for solid oxide fuel cells, Materials Science and Engineering: A. 397 (2005) 271-283. doi:10.1016/j.msea.2005.02.047.

[11] C.M. Huang, S.S. Shy, C.H. Lee, On flow uniformity in various interconnects and its influence to cell performance of planar SOFC, Journal of Power Sources. 183 (2008) 205213. doi:10.1016/j.jpowsour.2008.04.059.

[12] T.T. Molla, K. Kwok, H.L. Frandsen, Modeling the Mechanical Integrity of Generic Solid Oxide Cell Stack Designs Exposed to Long-term Operation, Fuel Cells. 19 (2019) 96-109. doi:10.1002/fuce.201800081.

[13] C. Schluckner, V. Subotić, S. Preiß1, C. Hochenauer, Numerical analysis of flow configurations and electrical contact positions in SOFC single cells and their impact on local effects, International Journal of Hydrogen Energy. 44 (2019) 1877-1895. doi:10.1016/j.ijhydene.2018.11.132.

[14] M. Canavar, Y. Kaplan, Effects of mesh and interconnector design on solid oxide fuel cell performance, International Journal of Hydrogen Energy. 40 (2015) 7829-7834. doi:10.1016/j.ijhydene.2014.11.101.

[15] M. Canavar, A. Mat, S. Celik, B. Timurkutluk, Y. Kaplan, Investigation of temperature distribution and performance of SOFC short stack with/without machined gas channels, International Journal of Hydrogen Energy. 41 (2016) 10030-10036. doi:10.1016/j.ijhydene.2016.02.045. 
[16] J.-Y. Baek, S.-J. Park, S.-B. Lee, J.-W. Lee, T.-H. Lim, R.-H. Song, K.-B. Kim, D.-R. Shin, Development of LSM-Coated Crofer Mesh for Current Collectors in Solid Oxide Fuel Cells, Journal of the Korean Electrochemical Society. 13 (2010) 256-263. doi:10.5229/JKES.2010.13.4.256.

[17] A. Morán-Ruiz, K. Vidal, A. Larrañaga, M.A. Laguna-Bercero, J.M. Porras-Vázquez, P.R. Slater, M.I. Arriortua, LaNi0.6Co0 $4 \mathrm{O} 3-\delta$ dip-coated on $\mathrm{Fe}-\mathrm{Cr}$ mesh as a composite cathode contact material on intermediate solid oxide fuel cells, Journal of Power Sources. 269 (2014) 509-519. doi:10.1016/j.jpowsour.2014.07.040.

[18] B.-K. Park, R.-H. Song, S.-B. Lee, T.-H. Lim, S.-J. Park, W. Jung, J.-W. Lee, Conformal bilayered perovskite/spinel coating on a metallic wire network for solid oxide fuel cells via an electrodeposition-based route, Journal of Power Sources. 348 (2017) 40-47. doi:10.1016/j.jpowsour.2017.02.080.

[19] K. Hilpert, D. Das, M. Miller, D.H. Peck, R. Weiß, Chromium Vapor Species over Solid Oxide Fuel Cell Interconnect Materials and Their Potential for Degradation Processes, J. Electrochem. Soc. 143 (1996) 3642-3647. doi:10.1149/1.1837264.

[20] M. Stanislowski, E. Wessel, K. Hilpert, T. Markus, L. Singheiser, Chromium Vaporization from High-Temperature Alloys I. Chromia-Forming Steels and the Influence of Outer Oxide Layers, J. Electrochem. Soc. 154 (2007) A295-A306. doi:10.1149/1.2434690.

[21] H. Yokokawa, T. Horita, N. Sakai, K. Yamaji, M.E. Brito, Y.-P. Xiong, H. Kishimoto, Thermodynamic considerations on $\mathrm{Cr}$ poisoning in SOFC cathodes, Solid State Ionics. 177 (2006) 3193-3198. doi:10.1016/j.ssi.2006.07.055.

[22] B. Talic, H. Falk-Windisch, V. Venkatachalam, P.V. Hendriksen, K. Wiik, H.L. Lein, Effect of coating density on oxidation resistance and $\mathrm{Cr}$ vaporization from solid oxide fuel cell interconnects, Journal of Power Sources. 354 (2017) 57-67. doi:10.1016/j.jpowsour.2017.04.023.

[23] S. Molin, P. Jasinski, L. Mikkelsen, W. Zhang, M. Chen, P.V. Hendriksen, Low temperature processed $\mathrm{MnCo}_{2} \mathrm{O}_{4}$ and $\mathrm{MnCo}_{1 .} \mathrm{Fe}_{0.2} \mathrm{O}_{4}$ as effective protective coatings for solid oxide fuel cell interconnects at $750{ }^{\circ} \mathrm{C}$, Journal of Power Sources. 336 (2016) 408-418. doi:10.1016/j.jpowsour.2016.11.011.

[24] L. Besra, M. Liu, A review on fundamentals and applications of electrophoretic deposition (EPD), Progress in Materials Science. 52 (2007) 1-61. doi:10.1016/j.pmatsci.2006.07.001.

[25] Z. Sun, R. Wang, A.Y. Nikiforov, S. Gopalan, U.B. Pal, S.N. Basu, CuMn1.8O4 protective coatings on metallic interconnects for prevention of Cr-poisoning in solid oxide fuel cells, Journal of Power Sources. 378 (2018) 125-133. doi:10.1016/j.jpowsour.2017.12.031.

[26] M. Mirzaei, A. Simchi, M.A. Faghihi-Sani, A. Yazdanyar, Electrophoretic deposition and sintering of a nanostructured manganese-cobalt spinel coating for solid oxide fuel cell interconnects, Ceramics International. 42 (2016) 6648-6656. doi:10.1016/j.ceramint.2016.01.012.

[27] Y. Zhang, A. Javed, M. Zhou, S. Liang, P. Xiao, Fabrication of Mn-Co Spinel Coatings on Crofer 22 APU Stainless Steel by Electrophoretic Deposition for Interconnect Applications in Solid Oxide Fuel Cells, Int. J. Appl. Ceram. Technol. 11 (2014) 332-341. doi:10.1111/ijac.12013.

[28] F. Smeacetto, A. De Miranda, S. Cabanas Polo, S. Molin, D. Boccaccini, M. Salvo, A.R. Boccaccini, Electrophoretic deposition of $\mathrm{Mn}_{1.5} \mathrm{Co}_{1.5} \mathrm{O}_{4}$ on metallic interconnect and interaction with glass-ceramic sealant for solid oxide fuel cells application, Journal of Power Sources. 280 (2015) 379-386. doi:10.1016/j.jpowsour.2015.01.120. 
[29] E. Zanchi, B. Talic, A.G. Sabato, S. Molin, A.R. Boccaccini, F. Smeacetto, Electrophoretic co-deposition of $\mathrm{Fe} 2 \mathrm{O} 3$ and $\mathrm{Mn} 1,5 \mathrm{Co} 1,5 \mathrm{O} 4$ : processing and oxidation performance of $\mathrm{Fe}$ doped Mn-Co coatings for solid oxide cell interconnects, Journal of the European Ceramic Society. (2019). doi:10.1016/j.jeurceramsoc.2019.05.024.

[30] L.V. Gambino, N.J. Magdefrau, M. Aindow, Microstructural effects of the reduction step in reactive consolidation of manganese cobaltite coatings on Crofer 22 APU, Materials at High Temperatures. 32 (2015) 142-147. doi:10.1179/0960340914Z.00000000090.

[31] M. Bobruk, S. Molin, M. Chen, T. Brylewski, P.V. Hendriksen, Sintering of MnCo 2 O 4 coatings prepared by electrophoretic deposition, Materials Letters. 213 (2018) 394-398. doi:10.1016/j.matlet.2017.12.046.

[32] S.R. Akanda, N.J. Kidner, M.E. Walter, Spinel coatings on metallic interconnects: Effect of reduction heat treatment on performance, Surface and Coatings Technology. 253 (2014) 255-260. doi:10.1016/j.surfcoat.2014.05.049.

[33] S.R. Akanda, M.E. Walter, N.J. Kidner, M.M. Seabaugh, Mechanical characterization of oxide coating-interconnect interfaces for solid oxide fuel cells, Journal of Power Sources. 210 (2012) 254-262. doi:10.1016/j.jpowsour.2012.03.008.

[34] H.L. Frandsen, E. Olevsky, T.T. Molla, V. Esposito, R. Bjørk, N. Pryds, Modeling sintering of multilayers under influence of gravity, Journal of the American Ceramic Society. 96 (2013) 80-89. doi:10.1111/jace.12070.

[35] T.T. Molla, R. Bjørk, E. Olevsky, N. Pryds, H.L. Frandsen, Multi-scale modeling of shape distortions during sintering of bi-layers, Computational Materials Science. 88 (2014) 28-36. doi:10.1016/j.commatsci.2014.02.041.

[36] T.T. Molla, D.W. Ni, R. Bulatova, R. Bjørk, C. Bahl, N. Pryds, H.L. Frandsen, Finite Element Modeling of Camber Evolution During Sintering of Bilayer Structures, Journal of the American Ceramic Society. 97 (2014) 2965-2972. doi:10.1111/jace.13025.

[37] R.K. Bordia, A. Jagota, Crack Growth and Damage in Constrained Sintering Films, Journal of the American Ceramic Society. 76 (1993) 2475-2485. doi:10.1111/j.11512916.1993.tb03969.x.

[38] J.W. Hutchinson, Z. Suo, Mixed Mode Cracking in Layered Materials, in: J.W. Hutchinson, T.Y. Wu (Eds.), Advances in Applied Mechanics, Elsevier, 1991: pp. 63-191. doi:10.1016/S0065-2156(08)70164-9.

[39] T. Tadesse Molla, F. Greco, K. Kwok, P. Zielke, H.L. Frandsen, Development of high temperature mechanical rig for characterizing the viscoplastic properties of alloys used in solid oxide cells, Journal of Testing and Evaluation. 46 (2018). doi:10.1520/JTE20170046.

[40] E. a. Olevsky, Theory of sintering: from discrete to continuum, Materials Science and Engineering: R: Reports. 23 (1998) 41-100. doi:10.1016/S0927-796X(98)00009-6.

[41] R. Sachitanand, J.-E. Svensson, J. Froitzheim, The Influence of Cr Evaporation on Long Term Cr Depletion Rates in Ferritic Stainless Steels, Oxid Met. 84 (2015) 241-257. doi:10.1007/s11085-015-9552-5.

[42] H. Kurokawa, C.P. Jacobson, L.C. DeJonghe, S.J. Visco, Chromium vaporization of bare and of coated iron-chromium alloys at 1073 K, Solid State Ionics. 178 (2007) 287-296. doi:10.1016/j.ssi.2006.12.010.

[43] J. Froitzheim, G.H. Meier, L. Niewolak, P.J. Ennis, H. Hattendorf, L. Singheiser, W.J. Quadakkers, Development of high strength ferritic steel for interconnect application in SOFCs, Journal of Power Sources. 178 (2008) 163-173. doi:10.1016/j.jpowsour.2007.12.028. 
[44] H. Falk-Windisch, J.E. Svensson, J. Froitzheim, The effect of temperature on chromium vaporization and oxide scale growth on interconnect steels for Solid Oxide Fuel Cells, Journal of Power Sources. 287 (2015) 25-35. doi:10.1016/j.jpowsour.2015.04.040.

[45] P. Huczkowski, S. Ertl, J. Piron-Abellan, N. Christiansen, T. Höfler, V. Shemet, L. Singheiser, W. j. Quadakkers, Effect of component thickness on lifetime and oxidation rate of chromia forming ferritic steels in low and high pO2 environments, Materials at High Temperatures. 22 (2005) 253-262. doi:10.1179/mht.2005.029.

[46] K. Yamamoto, Y. Kimura, Y. Mishima, Effect of matrix microstructure on precipitation of Laves phase in Fe-10Cr-1.4W(-Co) alloys, Intermetallics. 14 (2006) 515-520. doi:10.1016/j.intermet.2005.09.005.

[47] Z.-W. Hsiao, B. Kuhn, D. Chen, L. Singheiser, J.-C. Kuo, D.-Y. Lin, Characterization of Laves phase in Crofer $22 \mathrm{H}$ stainless steel, Micron. 74 (2015) 59-64. doi:10.1016/j.micron.2015.04.007.

[48] H. Falk-Windisch, M. Sattari, J.-E. Svensson, J. Froitzheim, Chromium vaporization from mechanically deformed pre-coated interconnects in Solid Oxide Fuel Cells, Journal of Power Sources. 297 (2015) 217-223. doi:10.1016/j.jpowsour.2015.07.085.

[49] R. Berger, M.W. Lundberg, J. Westlinder, H. Holmberg, Self Healing of Precoated AISI 441 for Solid Oxide Fuel Cell Interconnects, ECS Trans. 68 (2015) 1649-1655. doi:10.1149/06801.1649ecst.

[50] N. Grünwald, D. Sebold, Y.J. Sohn, N.H. Menzler, R. Vaßen, Self-healing atmospheric plasma sprayed Mn1.0Co1.9Fe0.104 protective interconnector coatings for solid oxide fuel cells, Journal of Power Sources. 363 (2017) 185-192. doi:10.1016/j.jpowsour.2017.07.072. 